\title{
Deadly Mistakes: Harmless Error in Capital Sentencing
}

Almost every criminal defendant who is found guilty can find some mistake in the proceedings leading to his conviction. Because reversal for all such errors would be too costly and would undermine public confidence in the criminal justice system, courts and legislatures have developed "harmless error" rules that uphold a decision tainted by error if the error is found not to have affected the outcome at trial. The rules, contained in both common law and statutes, reach even those errors that affect the constitutional rights of the defendant. Although many commentators have criticized these rules, ${ }^{1}$ both federal and state appellate courts use them consistently.

Many courts have used a harmless error test to affirm even capital sentences, arguing that defendants facing the death penalty have no more right to an error-free proceeding than do other defendants. However, application of the harmless error doctrine is inappropriate in a capital case where error is found in the sentencing phase rather than in the trial of guilt. The primary difference between capital sentencing and noncapital sentencing is that sentencers in capital cases have vast discretion to hear any mitigating evidence available to the defense and to impose a life sentence despite compelling aggravating circumstances. In the face of such sentencing discretion, an appellate court cannot meaningfully conclude that an error had no impact on the jury's sentence. The reviewing court is disabled from assessing the impact of both constitutional and nonconstitutional errors alike in the context of capital sentencing. This comment therefore concludes that the harmless error doctrine never should be used to affirm the outcome of flawed capital sentencing proceedings.

Part I of this comment outlines the development of harmless error rules, including the policy underlying their use and their application in capital sentencing. Part II delves deeper into the

1 See, e.g., Steven H. Goldberg, Harmless Error: Constitutional Sneak Thief, $71 \mathrm{~J}$. Crim. L. \& Criminology 421, 421 (1980) (" 'Harmless constitutional error' is among the most insidious of legal doctrines."); Note, Harmful Use of Harmless Error in Criminal Cases, 64 Cornell L. Rev. 538, 565 (1979). 
unique aspects of capital sentencing that compel restrictions on the rule; it concludes that both the practical and substantive differences between capital sentencing and other criminal proceedings preclude the use of the harmless error test to assess the impact of errors in capital punishment hearings.

\section{The Harmless Error Test:}

Development and Application in Capital Sentencing

\section{A. Background}

The harmless error test, used often by appellate courts, ${ }^{2}$ was at first a narrow exception to a per se rule. The test responded to the traditional common law rule that required automatic reversal when error in trial proceedings was proven, even if the error had not affected the outcome of the case. ${ }^{3}$ Automatic reversal was widely condemned as a waste of judicial resources. Courts were labeled "impregnable citadels of technicality" because they reflexively reversed sound decisions infected with minor procedural mistakes, often compelling expensive retrials where the outcome almost always duplicated the original result. ${ }^{5}$ However, critics were not only concerned with judicial economy; they were also worried that a rule requiring reversal of convictions on the ground of technical errors would undermine public respect for the judicial system. ${ }^{6}$ Moreover, the concern that the appellate court's determination of harmlessness would usurp the jury's function was counterbalanced by the notion that reversing fundamentally sound jury verdicts also, and perhaps more fundamentally, usurped this

2 See United States v. Lane, 106 S.Ct. 725, 744 (1986) (Stevens, dissenting) (noting increased use of harmless error tests).

3 Although the rule in Crease v. Barrett, 149 Eng.Rep. 1353, 1359 (Exch. 1835), seemed to allow for a limited harmless error approach, English and American courts adopted an absolute reversal approach. See Roger Traynor, The Riddle of Harmless Error 8, 11-13 (1970). See also John Henry Wigmore, 1 Wigmore on Evidence $\$ 21$ at 364 (3d ed. 1940); Goldberg, 71 J. Crim. L. \& Criminology at 422 (cited in note 1); Note, Harmless Error: The Need for a Uniform Standard, 53 St. John's L. Rev. 541, 543-45 (1979).

- Marcus A. Kavanagh, Improvement of Administration of Criminal Justice by Exercise of Judicial Power, 11 A.B.A. J. 217-22 (1925), quoted in Kotteakos v. United States, 328 U.S. 750, 750, 759 (1946). See Traynor, Harmless Error at 14-15 (cited in note 3) ("There had to be an end to battles of bright or dull wits in the courtroom on witless technicalities.").

S See Lane, 106 S.Ct. at 743 (Stevens, dissenting); United States v. Hasting, 461 U.S. 499, 509 (1983); 1 Wigmore on Evidence $\S 21$ at 370-73 (cited in note 3).

- See Delaware v. Van Arsdall, 106 S.Ct. 1431, 1436-37 (1986) (harmless error doctrine "promotes public respect for the criminal process by focusing on the underlying fairness of the trial rather than on the virtually inevitable presence of immaterial error"); Traynor, Harmless Error at 14, 35 (cited in note 3). 
role. $^{7}$

Pressures for reform led to statutory and common law rules for harmless error. The first federal statutory harmless error rule only applied when "technical" errors were found; if an error affected the substantive rights of the parties, the case would be reversed. ${ }^{8}$ Later, Congress expanded the federal statute to reach all nonconstitutional errors, including nontechnical ones. But the test for reversal continued to be whether the error affected the "substantial" rights of the parties. "The Supreme Court ruled that this test was satisfied only when the error affected the trial's outcome. ${ }^{10}$

Thus, a two-step test determines whether a criminal conviction must be reversed for nonconstitutional error. The party claiming the error must persuade the reviewing court first that there was an error in the proceeding, and second that the error affected the outcome of the trial. ${ }^{11}$ By examining the error itself-or, in the case of an evidentiary error, the totality of the case presented to the jury-the court decides whether the error was harmless. ${ }^{12}$

In Chapman v. California, the Supreme Court approved the application of the harmless error test to constitutional errors in criminal trials. ${ }^{13}$ The Court recognized the utility of harmless error rules that "block setting aside convictions for small errors or defects that have little, if any, likelihood of having changed the result

7 1 Wigmore on Evidence $\$ 21$ at 370 (cited in note 3) ("The 'usurpation' [of the jury's role], if any, consists in setting aside the verdict, not in confirming it.").

828 U.S.C. § 391 (1946).

- See, for example, 28 U.S.C. § 2111 (1982); Fed. Rule Crim. Proc. 52(a).

${ }^{20}$ Kotteakos, 328 U.S. at 760-65 ('[The statute] 'affects only technical errors.' . . . But if one cannot say, with fair assurance . . . that the judgment was not substantially swayed by the error, it is impossible to conclude that substantial rights were not affected.").

The test that considers whether the error affected the reliability of the result applies only to errors that alter the presentation of the evidence to the jury. The effect of structural error-errors that involve, for instance, venue and pleadings-can be determined independently of the evidence presented to the accused. Thus the test for these errors looks at the error itself-without any focus on its impact on the decision maker-to determine whether it deprived the defendant of the substantive right the structural rule was intended to protect. This strand of the harmless error test, however, does not usurp jury decision making or throw into question the determination of guilt, and it is not controversial. Wayne R. Lafave and Jerold Israel, 3 Criminal Procedure $\S 26.6$ (a) at 259-60 (1984). This comment deals with evidentiary errors in capital sentencing and does not extend to structural errors.

${ }^{11}$ Kotteakos, 328 U.S. at 764 ("[T] their judgment, regardless of the error or its effect upon the verdict. It is rather what effect the error had or reasonably may be taken to have had upon the jury's decision. The critical thing is the impact of the thing done wrong on the minds of other men, not on one's own, in the total setting."). See also Lane, 106 S.Ct. at 732.

${ }^{12}$ See, e.g., Lane, $106 \mathrm{~S}$.Ct. at 732 (joinder violation harmless because overwhelming evidence available regarding guilt).

1s 386 U.S. 18 (1967). 
of the trial." The Court held that constitutional errors that are "unimportant or insignificant" in a trial can be deemed harmless, just as nonconstitutional errors can; only those errors that affect the substantial rights of the parties require reversal. ${ }^{14}$

The Chapman test, like the nonconstitutional standard, determines whether the error affected the substantive rights of the parties by looking at the effect of the error on the trial's outcome. ${ }^{15}$ Relying on its earlier decision in Fahy $v$. Connecticut, ${ }^{16}$ the Court in Chapman said the "question is whether there is a reasonable possibility that the evidence complained of might have contributed to the conviction."17 Under Chapman, then, the reviewing court must decide first whether constitutional error occurred and then whether, beyond a reasonable doubt, the error affected the outcome of the trial. For example, even if the jury heard evidence that was obtained in violation of the fourth amendment's prohibition of unreasonable searches and seizures, the reviewing court will sustain the conviction if the evidence did not contribute to the trial outcome. $^{18}$

14 Id. at 22, 23. Before Chapman, the Court had suggested that the harmless error doctrine might be inappropriate where the errors were of constitutional magnitude. See Kotteakos, 328 U.S. at 764-65 ("If, when all is said and done, the conviction [sic] is sure that the error did not influence the jury, or had but very slight effect, the verdict and the judgment should stand, except perhaps where the departure is from a constitutional norm or a specific command of Congress.") (emphasis added); Lane, 106 S.Ct. at 738 (Brennan, concurring). Even after Chapman, however, it is not clear to what extent Congress could affect the constitutional rule by legislation. See Chapman, 386 U.S. at 21; Traynor, Harmless Error at 41 (cited in note 3 ).

is 386 U.S. at 23.

18 375 U.S. 85 (1963) (reversing conviction, holding that it was not harmless error for trial judge to admit evidence obtained from illegal search and seizure where the evidence was prejudicial to the defendant).

${ }^{17}$ Chapman, 386 U.S. at 23, citing Fahy, 375 U.S. at 86-87.

18 See Chambers v. Maroney, 399 U.S. 42, 53 (1970); Whiteley v. Warden, 401 U.S. 560 (1971) (harmless error test applies to violations of the fourth amendment).

The second phase of the Chapman test takes one of two forms: the so-called "affect" test or the "overwhelming evidence" test. For a general discussion, see Martha A. Field, Assessing the Harmlessness of Federal Constitutional Error-A Process in Need of a Rationale, 125 U. Pa. L. Rev. 15, 16-36 (1976).

Under the "affect" test, the reviewing court focuses on the erroneously admitted evidence and asks whether it affected the outcome of the trial. This approach finds support in Chapman itself. See 386 U.S. at 23. See also Comment, Connecticut v. Johnson: Will the Use of the Sandstrom Instruction Trigger the Automatic Reversal Rule?, 19 New Eng. L. Rev. 487, 494-95 (1984). This is an effective way to test for harmlessness because in many cases the reviewing court is able to determine that an error did not contribute to the trial outcome, independent of the other evidence presented to the jury. See Traynor, Harmless Error at 36 (cited in note 3 ).

The "overwhelming evidence" test, on the other hand, looks to the evidence properly admitted to determine whether the jury would have reached a similar result had the tainted 
However, in several important ways the test for harmlessness of constitutional errors differs from that for nonconstitutional errors. First, once a constitutional error is found, the burden shifts to the state to prove its harmlessness; the burden does not shift for nonconstitutional errors. ${ }^{19}$ Second, the reviewing court must be persuaded "beyond a reasonable doubt" that the error did not affect the trial outcome in order to deem the error "harmless"-a stricter standard of persuasion than that for nonconstitutional error. ${ }^{20}$ And most importantly, some constitutional errors never can be deemed harmless, whereas any nonconstitutional error may be considered harmless in a particular case. ${ }^{21}$ In Chapman itself, both the plurality and the dissent stated that certain constitutional errors are never harmless. ${ }^{22}$

Both the constitutional and the nonconstitutional harmless error tests reflect a balancing of the defendant's interests in an errorfree proceeding against the societal interest in finality and judicial economy. This balancing is at the heart of the harmless error doctrine. ${ }^{23}$ The differences between the tests reflect the Court's view

evidence not been admitted. While it finds support in Supreme Court decisions-for example, Milton v. Wainwright, 407 U.S. 371, 372-73 (1972)-it has faced heated criticism from commentators, since it asks, in effect, whether the same decision would be upheld by a new jury on retrial. Such an outcome, the commentators argue, is unpredictable, given the uncertainties of trial tactics, judicial rulings, and jury responses. Field, $125 \mathrm{U}$. Pa. L. Rev. at 21-22 (cited in this note); Note, 53 St. John's L. Rev. at 550 (cited in note 3).

In practice, both of these tests indicate courts' willingness to compare the illegally admitted evidence with the evidence properly admitted to assess the harmfulness of the error. Even under the strict "affect" approach, under which the court formally should look only to the particular item to determine its importance in the trial, the error can be deemed harmless if there was overwhelming evidence in front of the jury. Overwhelming evidence against the defendant would suggest that the jury did not use the erroneously admitted evidence in finding the defendant guilty or in sentencing him.

${ }^{18}$ Chapman, 386 U.S. at 24 ("Certainly error, constitutional error, in illegally admitting highly prejudicial evidence or comments, casts on someone other than the person prejudiced by it a burden to show that it was harmless.").

${ }^{20}$ See Lane, 106 S.Ct. at $730 \mathrm{n} .9$ (noting that the Chapman standard is "considerably more onerous than the standard for non-constitutional errors"). See also Traynor, Harmless Error at 44 (cited in note 3) (arguing the beyond a reasonable doubt standard is a "belief approaching certainty").

${ }^{21}$ Kotteakos, 328 U.S. at 764-65. In addition, the nonconstitutional harmless error test is applied both to evidentiary and to structural errors. By contrast, the constitutional harmless error rule is applied only to those errors that implicate the jury's decision; so-called structural errors result in automatic reversal.

${ }^{22}$ Chapman, 386 U.S. at 23 n.8, citing Payne v. Arkansas, 356 U.S. 560 (1958) (coerced confession); Gideon v. Wainwright, 372 U.S. 335 (1963) (denial of right to counsel); Tumey v. Ohio, 273 U.S. 510 (1927) (biased judge).

${ }^{23}$ See United States v. Hasting, 461 U.S. 499, 502 (1983) (criticizing the lower court for its failure "to strike the balance between disciplining the prosecutor on the one hand, and the interest in the prompt administration of justice and the interests of the victims on the 
that a defendant's interests in a proceeding free of constitutional error are of a different magnitude than her interest in a proceeding free of any error whatsoever, even if the likely effect on the outcome is no different as between constitutional and nonconstitutional errors. ${ }^{24}$

In particular, some constitutional errors require automatic reversal, whereas no nonconstitutional mistakes require similar treatment. Nonconstitutional error does not in itself violate the defendant's constitutional rights unless the error so influenced the jury's decision that impinged upon the right to a fair trial. Thus, reversal for nonconstitutional error is necessary only when the error affected the outcome. But constitutional error in itself violates a constitutional norm, without reference to the impact of the error on the fact finder. This distinction may underlie the Court's willingness to find that some constitutional errors require automatic reversal.

The constitutional errors that require automatic reversal are of two kinds: (1) errors that are so fundamental to the constitutional right to a fair trial that they independently require reversal; and (2) errors that inherently make application of the outcomedeterminative test impossible. ${ }^{25}$

The first group of errors that demand automatic reversal comprises those that "necessarily render a trial fundamentally unfair" and undermine basic protections necessary for the fair determination of guilt or innocence. ${ }^{26}$ These errors include adjudication by a biased judge and complete denial of the right to counsel. ${ }^{27}$ They may also include those errors that do not directly implicate the defendant's interest in a fair trial, but instead affect interests extraneous to the trial process. One example is a violation of the double jeopardy clause, which, while not itself infringing the defendant's right to a fair trial, nonetheless requires automatic reversal to protect other interests of the defendant. ${ }^{28}$

The second group of errors that require automatic reversal are

other"). Indeed, interests in judicial economy and public respect triggered the adoption of harmless error rules.

24 See Stephen A. Saltzburg, The Harm of Harmless Error, 59 Va. L. Rev. 988, 1024-25 (1973); Note, 64 Cornell L. Rev. at 550-51 (cited in note 1).

26 See Van Arsdall, 106 S.Ct. at 1437; Lane, 106 S.Ct. at 745 (Stevens, dissenting); LaFave and Israel, 3 Criminal Procedure $\$ 26.6(\mathrm{~d})$ at 272-77 (cited in note 10).

26 See Rose v. Clark, 106 S.Ct. 3101, 3106 (1986) (collecting cases).

27 Tumey, 273 U.S. 510; Gideon, 372 U.S. 335.

${ }^{28}$ Price v. Georgia, 398 U.S. 323, 331-32 (1970). See Chapman, 386 U.S. at 52 n.7 (Harlan, dissenting), 42-43 (Stewart, concurring). See also Lafave and Israel, 3 Criminal Procedure $\S 26.6$ (d) at $273-74$ (cited in note 10). 
those with indeterminate effects on the trial. In these cases-such as improperly obtained confessions ${ }^{29}$ or unconstitutional presumptions ${ }^{30}$ - the effect of the error is so pervasive or uncertain that the reviewing court is unable to decide whether or not the error was harmless.

The errors for which automatic reversal is not required are those most susceptible to the Chapman test: errors (mainly evidentiary ones ${ }^{31}$ ) whose effect on the outcome can be measured by comparing them against an objective evidentiary standard. Under Chapman, all those errors that do not implicate fundamental interests of the defendant independent of the evidence presented or do not have an inherently indeterminate impact, may be deemed "harmless." 32 But even when other errors are challenged, the predicate for harmless error review still is the reviewing court's ability to discover the impact of the error on the decision maker below. According to the Court, the question is, "[W]hat is to be done about a trial error that, in theory, may have altered the basis on which the jury decided the case, but in practice had no effect on the outcome?"33

\section{B. Application of the Chapman Rule in Capital Sentencing}

1. Lower court cases. Some appellate courts recognize that application of the harmless error test to capital sentencing proceedings is difficult. Since capital sentencers have broad discretion, some courts refuse to embark on a procedure that requires a prediction of the error's impact on the sentencer's decision-making process. Because the sentencer may consider any evidence in mitigation of the death penalty and even may refuse to recommend death in the face of strong aggravating circumstances, these courts doubt their ability to determine the impact of the error on the sentencer. ${ }^{34}$ Other courts hold that since the sentencer may balance

29 See Chapman, 386 U.S. at 52 n.7 (Harlan, dissenting), citing Payne v. Arkansas, 356 U.S. 560 (1958).

so Id. at 43-44 (Stewart, concurring). See also Holloway v. Arkansas, 435 U.S. 475, 49091 (1978).

31 See Lafave \& Israel, 3 Criminal Procedure \$ 26.6(d) at 276 (cited in note 10) ("the Chapman harmless error rule has been applied by the Supreme Court to a wide range of constitutional evidentiary related errors").

${ }^{32}$ See Rose, 106 S.Ct. at 3106 (errors that per se require remand "are the exception and not the rule").

${ }^{3 s}$ Rose, 106 S.Ct. at 3108 n.11.

s4 See Ritter v. Smith, 726 F.2d 1505, 1518-19 (11th Cir. 1984); State v. David, 425 So.2d 1241, 1250 (La. 1983); King v. State, 657 S.W.2d 109, 112 (Tex. Crim. App. 1983). 
the aggravating and mitigating circumstances in whatever way it chooses, errors in admitting evidence so infect the entire sentencing process as to require a reversal of the decision. ${ }^{36}$ Still others say that even if an assessment of the error's impact were possible, the cost of a mistake in death cases is too high to risk affirming the decision. ${ }^{\text {s6 }}$

Many courts, however, use the harmless error test in capital cases just as in noncapital cases. Even if the constitutional error tainted the evidence presented to the sentencer, some courts nevertheless find the error harmless beyond a reasonable doubt. These courts try to expunge the evidence from the sentencing calculus after trial and to determine-independently and on the basis of a cold record-what the outcome would have been without the tainted information.

For example, in State v. Rushing, a Louisiana court affirmed a death sentence resulting from a sentencing hearing in which a lay witness improperly opined that the murder was committed in a particularly cruel, heinous, and atrocious manner. ${ }^{37}$ This is a constitutional defect because the opinion usurps the role of the jury. But even though the damaging statement was especially compelling because it was made by a police detective, who stated it was one of the most vicious attacks he had ever seen, the court ruled that "the jury could have determined from the other [untainted] evidence that the murder was committed in a cruel, atrocious or heinous manner. . . . A Any error in the admission of the lay witness opinion was harmless and did not influence the jury in returning the death sentence."38

In other death sentencing cases, courts have undertaken similar analyses. In many, courts have determined that the tainted evidence, though actually presented to the sentencer, was nonetheless

ss People v. Brown, 40 Cal.3d 512, 536-37, 220 Cal.Rptr. 637, 709 P.2d 440, 452-53 (1985); People v. Frank, 38 Cal.3d 711, 735, 214 Cal.Rptr. 801, 700 P.2d 415, 428 (1985) (error in admitting notebooks at penalty phase "infected the entire proceeding on this question, and was therefore prejudicial under any test"); Cannaday v. State, 455 So.2d 713, 724 (Miss. 1984) (admitting incriminating statement received in violation of sixth amendment in sentencing phase not harmless, because it "so infected the sentencing phase that reversal of that phase must be ordered").

s6 State v. Smith, 136 Ariz. 273, 280, 665 P.2d 995, 1002 (1983); People v. Brisbon, 106 Ill.2d 342, 371-72, 478 N.E.2d 402, 415-16 (1985); Miracle v. Commonwealth, 646 S.W.2d 720, 721 (Ky. 1983); Johnson v. State, 439 A.2d 542, 562 (Md. 1982); King, 657 S.W.2d at 112.

37464 So.2d 268, 275 (La. 1985).

ss Id. See also Jones v. State, 660 P.2d 634, 643 (Ok. Crim. App. 1983) (error in admitting letter not accompanied by testimony of person with knowledge of contents deemed harmless, since other evidence supporting claim was admitted). 
harmless since it was cumulative of other evidence properly before the jury. ${ }^{38}$ Similarly, when trial courts have blocked mitigating evidence from the proceedings, reviewing courts have nonetheless affirmed if the evidence was cumulative. ${ }^{40}$ Finally, other courts have affirmed sentences after looking at the tainted evidence and determining that it was so irrelevant as not to affect the sentencer's deliberations. ${ }^{41}$

2. Supreme Court cases. In the past, lower courts probably varied in applying the harmless error test in capital punishment cases at least partially because the Supreme Court offered them little guidance. In Skipper v. South Carolina, the Court applied the Chapman test in a capital case's sentencing phase. ${ }^{42}$ Applying the test, the Court found the error not harmless; the justices, however, failed to discuss whether harmless error analysis should be applied to death sentencing, given the purposes underlying the Chapman test and the unique concerns associated with death sentencing.

Skipper does not settle the issue posed by this comment. Had the Court found the error harmless, it might have reconsidered its initial decision to apply the harmless error test. The Court did not analyze explicitly the appropriateness of the test's application. In fact, this silent adoption of the test seems odd at first glance, given the heated disagreement among lower courts on the issue and the equally heated discussions in the Supreme Court's prior harmless error cases. ${ }^{48}$

However, the Skipper Court's application of the test can be seen as the culmination of a recent line of cases that express dissatisfaction with automatic reversal rules in general. This trend can be seen most clearly in the progression from Connecticut $v$. Johnson ${ }^{44}$ to Rose v. Clark. ${ }^{45}$ In Johnson, the Court held unconstitutional an instruction that the jury in the guilt phase of a capital case could infer that the defendant had intended the natural con-

s9 See, e.g., Banks v. State, 701 P.2d 418, 425-26 (Ok. Crim. App. 1985) (error in admitting evidence of previous conviction harmless since evidence of two other previous convictions were validly admitted).

to State v. Patterson, 327 S.E.2d 650, 653-54 (S.C. 1984).

4 See Turner v. State, 685 S.W.2d 38, 44 (Tex. Crim. App. 1985) ("irrelevant" inadmissible evidence did not affect the sentencer's decision).

42106 S.Ct. 1669, 1672-73 (1986).

4s See, for example, Rose, 106 S.Ct. at 3113-16 (Blackmun, dissenting); Connecticut v. Johnson, 460 U.S. 73, 90-102 (1983) (Powell, dissenting).

4460 U.S. 73 (1983).

45106 S.Ct. 3101 (1986). 
sequences of his acts. ${ }^{46}$ More importantly, the plurality opinion indicated serious doubt that such an error could ever be deemed harmless, stating that the reviewing court could not predict the actual effect of the instruction on the jury's considerations. ${ }^{47}$

However, Rose, decided just three years later, strongly rejected the Johnson plurality's concerns. In Rose, the Court acknowledged that the jury instruction was unconstitutional; however, without referring to the concerns expressed in Johnson, the Court held that the Chapman test should apply to this kind of error. ${ }^{48}$ Over vigorous dissent, the Court stated that absolute remand is "the exception and not the rule." Skipper is just one more step along this line, revealing the Court's determination to apply harmless error analysis in almost all contexts. ${ }^{50}$ As Skipper illustrates, the Court has never distinguished capital sentencing from other types of cases when deciding whether to apply harmless error rules; the clear trend of the cases is against drawing such a distinction. Nonetheless, the capital sentencing context is different, and its peculiarities mandate automatic reversal for error in these cases.

\section{Automatic Reversal for ERrors in Capital Punishment Sentencing}

The impact of a constitutional error after Chapman must be assessed in the context of the proceeding in which the error occurred. ${ }^{\text {s1 }}$ Death sentencing hearings differ from ordinary trials: unique procedures and policies have been developed to take into account the severity and finality of the contemplated punishment. These procedures make it impossible for reviewing courts to make the determination central to harmless error analysis: that is, to determine with reasonable certainty that an error in the sentencing hearing had no effect on the sentencer's deliberations. Thus, when error-whether constitutional or not-is found in the sentencing

16460 U.S. at $86-88$ (plurality). The instruction violated Sandstrom v. Montana, 442 U.S. 510 (1979).

17460 U.S. at $87-88$ (plurality). This problem is similar to that of discerning the effect of errors on the sentencer in capital cases.

48 Rose, 106 S.Ct. at 3107-09.

"Id. at 3106.

so See also Pope v. Illinois, 55 U.S.L.W. 4595 (May 4, 1987) (remanding for application of harmless error test to improper jury instruction in obscenity case); Strickland v. Washington, 466 U.S. 668 (1984) (applying harmless error analysis to a sixth amendment claim of ineffective assistance of counsel).

s1 Kotteakos states that the "character of the proceeding, what is at stake upon its outcome," must be taken into account in determining harmlessness. 328 U.S. at 762. 
phase of a capital case, the sentence must be reversed.

\section{A. The Unique Aspects of Capital Sentencing}

Since its landmark decision in Furman v. Georgia, ${ }^{\mathrm{s2}}$ the Supreme Court has emphasized the uniqueness of death as a criminal punishment. Death is "an unusually severe punishment, unusual in its pain, in its finality, and in its enormity." "It differs from lesser sentences "not in degree but in kind. It is unique in its total irrevocability." Because of the death sentence's gravity, the Court has concluded that it may not be imposed unless certain procedural requirements have been met and unless the sentencer has been given the opportunity to dispense mercy if it so desires.

1. Procedural regularity. It is critically important to ensure that capital punishment is imposed without arbitrariness or caprice. The sentence must be as reliable ${ }^{58}$ and fair ${ }^{56}$ as procedures can make them. The defendant and society must be assured that death is the appropriate punishment in the specific case, ${ }^{57}$ particularly since its imposition often has seemed like "little more than a lottery system," poor, the ignorant, and the underprivileged members of society." 59 Thus "it is of vital importance to the defendant and to the community that any decision to impose the death sentence be, and appear to be, based on reason rather than caprice and emotion." $\mathrm{A}$ system of procedural regularity helps to ensure the achievement of these twin goals of fairness and reliability. ${ }^{61}$

62408 U.S. 238 (1972).

${ }^{83}$ Id. at 287 (Brennan, concurring).

${ }^{34}$ Id. at 306 (Stewart, concurring).

ss See Lockett v. Ohio, 438 U.S. 586, 604 (1978) (plurality) ("We are satisfied that this qualitative difference between death and other penalties calls for a greater degree of reliability when the death sentence is imposed."). See also Caldwell v. Mississippi, 472 U.S. 320, 330 (1985); Barclay v. Florida, 463 U.S. 939, 959 (1983) (Stevens, concurring); Furman, 408 U.S. at 310 (Stewart, concurring).

so See Eddings v. Oklahoma, 455 U.S. 104, 111 (1982) (beginning with Furman, the Court has attempted to provide constitutional standards for death penalty that would serve "both goals of measured, consistent application and fairness to the accused."). See also Proffit v. Florida, 428 U.S. 242, 252-53 (1976) (plurality).

s7 Woodson v. North Carolina, 428 U.S. 280, 305 (1976).

ss Furman, 408 U.S. at 293 (Brennan, concurring).

s5 Id. at 365-66 (Marshall, concurring). See also id. at 255-56 (Douglas, concurring), 274 (Brennan, concurring).

to Gardner v. Florida, 430 U.S. 349, 358 (1977). See also Eddings, 455 U.S. at 117-18 (O’Connor, concurring); Beck v. Alabama, 447 U.S. 625, 642-43 (1980).

${ }^{61}$ See Strickland, 466 U.S. at 704-05 (Brennan, concurring in part and dissenting in part); Eddings, 455 U.S. at 117-18 (O'Connor, concurring). 
The Supreme Court has translated the concern for procedural regularity into requirements that the sentencer's discretion in imposing the punishment be "channelled" and that the sentence be reviewed by appellate courts to avoid arbitrary or unfair application of the death penalty. ${ }^{62}$ By "channelling," the Court means that states must adopt statutes that distinguish between those defendants who deserve capital punishment and those who do not, ${ }^{63}$ and that guide juries as to those factors required to support the death penalty. ${ }^{64}$ Jurors must affirmatively find such factors before they may impose a sentence of death. ${ }^{65}$ Without such safeguards, there is an impermissible danger that death would be imposed "dependent on the whim of one man or [twelve]."

The Court has also required meaningful appellate review in death penalty cases. There must be a way "for the judiciary to check arbitrary and capricious exercise of that [sentencing] power through a review of death sentences." review the sentence for error ${ }^{68}$ and ensure that it was not imposed

62 Hopper v. Evans, 456 U.S. 605, 611 (1982), and cases cited therein. See also California v. Brown, 107 S.Ct. 837,839 (1987).

as For instance, the Court has criticized a Georgia death sentence based solely on a finding that the offense was " 'outrageously or wantonly vile, horrible and inhuman." "Godfrey, 446 U.S. at 428-29. Almost any murder could be so deemed, and thus this description of an aggravating circumstance gives the jury little guidance in determining which defendants deserve the death penalty.

o4 See Woodson, 428 U.S. at 303; Gregg v. Georgia, 428 U.S. 153, 192 (1976) (plurality) (jury should be given guidance "regarding the factors about the crime and the defendant that the State, representing organized society, deems particularly relevant to the sentencing decision"); Brown, 107 S.Ct. at 839.

The Court's recent decision in McCleskey v. Kemp, 107 S.Ct. 1756 (1987), seems inconsistent with the purposes of the channelling requirement. In $\mathrm{McCleskey,} \mathrm{the} \mathrm{Court} \mathrm{refused}$ to reverse a death sentence on the basis of statistical studies purporting to show that Georgia's death penalty statute was unfair in application, in that the sentence was far more likely to be imposed in cases involving a black defendant and a white victim than in any other circumstances. Id. at 1766 . The Court acknowledged this apparent disparity in application of the statute, but stated that such disparities are "inevitable" in our criminal justice system, id. at 1777, and held that so long as the Court's procedural requirements are met, the sentence will be upheld. Id. at 1788 .

One can argue that McCleskey is an merely an outgrowth of the Court's skepticism regarding the use of statistics to reverse criminal convictions. See id. at 4548 . On the other hand, the case may be seen as an acknowledgement that the flip side of the sentencer's discretion to impose mercy, is its discretion to impose death, once the threshold channelling requirements are met.

${ }^{\text {es }}$ See Proffitt, 428 U.S. at 257-58 (plurality). But see Barclay, 463 U.S. at 957 (plurality) ("no constitutional defect in a sentence based on both statutory and nonstatutory aggravating circumstances").

sa Furman, 408 U.S. at 253 (Douglas, concurring).

${ }^{67}$ Woodson, 428 U.S. at 303 (plurality). See also Gregg, 428 U.S. at 195 (plurality).

os Zant v. Stephens, 462 U.S. 862, 885 (1983) ("the severity of the sentence mandates careful scrutiny in the review of any colorable claim of error"). 
out of whim or prejudice. ${ }^{69}$ Moreover, the reviewing court must decide if the evidence supported the sentencer's finding of aggravating circumstances. ${ }^{70}$ Finally, in order to ensure further that the sentence is fair, the appellate court may compare the sentence with others given to similar defendants involved in similar circumstances, ${ }^{71}$ but it is not required to do so. ${ }^{72}$ These safeguards, set out by the Supreme Court and contained in state statutes, help to achieve fairness and reliability.

In most cases, the trial leading to conviction and a death sentence is bifurcated, with the same jury addressing the questions of guilt and punishment in two separate proceedings. ${ }^{73}$ In sentencing under this system, jurors generally must find explicit, statutorily defined aggravating circumstances before recommending death, ${ }^{\mathbf{7 4}}$ but at the same time they are allowed to consider a wide variety of evidence in mitigation. ${ }^{75}$ This is one of the purposes of the bifurcated system. To allow mitigating evidence in the sentencing pro-

69 Gregg, 428 U.S. at 198 (plurality).

70 Appellate review to ensure that the evidence supports the verdict differs from harmless error review. In the former, the court independently reweighs the same evidence the sentencer considered, as a check to ensure that enough evidence supported the sentence; in the latter, the court predicts what impact the error had on the actual sentencing deliberations by considering evidence that, in its totality, was different than that presented to the jury. See Cabana v. Bullock, 106 S.Ct. 689, 703 (1986) (Blackmun, dissenting). Nevertheless, review of a jury's finding of aggravated circumstances must include review of the evidence to determine if it supports the verdict, for that is the only way to discover if the sentence was based on whim or prejudice. Gregg, 428 U.S. at 198 (plurality).

" See Barclay, 463 U.S. at 958 (plurality); Proffitt, 428 U.S. at 258-59 (plurality); Gregg, 428 U.S. at 204-06 (plurality); Baldwin v. State, 456 So.2d 117, 126 (Ala. Crim. App. 1983).

72 Pulley v. Harris, 465 U.S. 37, 49-52 (1984).

73 See Note, The Presumption of Life: A Starting Point for a Due Process Analysis of Capital Sentencing, 94 Yale L. J. 351, 366 (1984) ("Bifurcation is perhaps the most distinctive feature of the capital punishment statutes upheld by the Supreme Court in 1976. It is a feature that all states with capital punishment statutes have subsequently adopted."). See also Stephen Gillers, Deciding Who Dies, 129 U. Pa. L. Rev. 1, 101-19 (1980) (chart of provisions in state capital punishment statutes).

74 See Note, 94 Yale L. J. at $368 \mathrm{n.103}$ (cited in note 73) (majority of states require that prosecution prove beyond a reasonable doubt the existence of at least one of the aggravating factors listed in the statute). See also Pulley, 465 U.S. at 53 ("By requiring the jury to find at least one special circumstance beyond a reasonable doubt, the statute limits the death sentence to a small subclass of capital-eligible cases.")

${ }^{75}$ See Note, 94 Yale L. J. at 368 n.103 ("The defendant can present any factors in mitigation and generally is not bound by the rules of evidence."). See also Hitchcock v. Dugger, 107 S.Ct. 1821 (1987) (reversing sentence where jury was not allowed to consider all evidence in mitigation); McCleskey, 107 S.Ct. at 1773 ("the Constitution limits a State's ability to narrow a sentencer's discretion to consider relevant evidence that might cause it to decline to impose the death sentence") (emphasis in original). 
ceeding even if it was excluded in the trial of guilt. ${ }^{76}$

At the sentencing proceeding, the prosecution has the burden of proving that the aggravating circumstances outweigh all mitigating circumstances. ${ }^{77}$ The jury recommendation either becomes the sentence for the defendant or is considered by the trial judge who makes the final determination..$^{78}$ After the trial, all states require reviewing courts to consider independently whether the evidence supports the sentence; most states also require the appellate court to check that the punishment does not differ greatly from punishments meted out to similar defendants in similar circumstances. ${ }^{79}$

2. Mitigation and mercy. The strict procedural safeguards required in death sentencing are not the only constitutional requirements unique to death sentencing. In order for the defendant to be treated as an individual human being rather than a member of " $a$ faceless, undifferentiated mass to be subjected to the blind infliction of the penalty of death," ual consideration to all mitigating circumstances surrounding the defendant and his crime. ${ }^{81}$ If the sentencer is prohibited from considering any factor in mitigation of the punishment, there is a risk that the death penalty will be imposed despite circumstances that would call for a less severe penalty. The Supreme Court has held that "[w]hen the choice is between life and death, that risk is unacceptable and incompatible with the commands of the Eighth and

76 Gregg, 428 U.S. at 191-92 (plurality).

77 While some states have written this requirement into their statutes, others have neglected to do so. See Note, 94 Yale L. J. at 368-69 \& n.107 (cited in note 73). The Supreme Court has acknowledged that it is appropriate to compel the jury to determine whether the prosecution has met its burden in the capital sentencing proceeding. Bullington, 451 U.S. at 444-45. See also Gillers, 129 U. Pa. L. Rev. at 101-19 (cited in note 73) (chart).

${ }^{78}$ See Note, 94 Yale L. J. at 365 n.90 (cited in note 73) (under most statutes, the sentence imposed by the jury is binding, although some states follow the Florida statute, which allows trial judges to reject jury sentences). See also Gillers, 129 U. Pa. L. Rev. at 101-19 (cited in note 73) (chart).

70 See Pulley, 465 U.S. at 144 (all of the state statutes drafted after Furman provide for automatic appeal of death sentences; most require proportionality review). See also Note, 94 Yale L. J. at 373 n.129, noting that most states provide for a three-part review to determine if (1) the sentence was imposed under influence of passion or prejudice, (2) the evidence fails to support the finding of an aggravating circumstance, or (3) the sentence is disproportionate to sentences in similar cases in the state.

so Woodson, 428 U.S. at 304 (plurality). This is not only "enlightened policy" but is also required by the eighth amendment. Id. at 304-05.

81 Eddings, 455 U.S. at 111-12; Gregg, 428 U.S. at 197 (plurality); Brown, 107 S.Ct. at 839. Thus the eighth and fourteenth amendments forbid statutes, Lockett, 438 U.S. at 605 (plurality), and trial court judges, Eddings, 455 U.S. at 112-15 (plurality), from denying sentencers the ability to consider any evidence in mitigation. 


\section{Fourteenth Amendments."}

Not only must jurors give individual consideration to all mitigating circumstances, but they also must have the freedom to impose a lesser penalty than death if they desire. Jurors may refuse to impose the death penalty regardless of the crime's circumstances. ${ }^{8 s}$ The sentencer's authority to dispense mercy further ensures that the punishment fits the individual circumstances of the case and reflects society's interests. ${ }^{84}$

In sum, the procedural requirements in death penalty cases all work in favor of the defendant. The sentencer is free to consider any factor in mitigation, in whatever way it chooses, and to impose mercy if it so desires. But, in considering aggravating circumstances, the sentencer must look only to those that are defined by statutes. The death penalty's procedural requirements thus establish an asymmetry in the sentencer's consideration of the aggravating and mitigating factors, ${ }^{85}$ an asymmetry that favors mitigation and mercy, and one that must be reinforced by vigorous appellate review. Each defendant must receive individualized consideration and the fullest chance to escape death.

\section{B. Inability to Perform the Chapman Test}

\section{As explained, harmless error doctrine requires reviewing}

${ }^{82}$ Lockett, 438 U.S. at 605 (plurality). Since it is important that sentencers consider all evidence in mitigation, rules of evidence are relaxed in the sentencing phase. See, e.g., Green v. Georgia, 442 U.S. 95, 95-97 (1979) (per curiam) (reversed sentence where trial court refused to admit hearsay evidence that tended to prove defendant did not commit murder); Gregg, 428 U.S. at 203-04 (plurality) ("So long as the evidence introduced and the arguments made at the presentence hearing do not prejudice a defendant, it is preferable not to impose restrictions."); Brisbon, 478 N.E.2d at 412 ("The only limitations upon evidence to be admitted at the aggravation and mitigation phases of the sentencing hearing are relevance and reliability; the hearing is not confined by rules of evidence in effect at the guilt phase of the trial."). In fact, one of the purposes of the bifurcated trial is to allow evidence to be presented in mitigation that was not allowed at the guilt phase. Eberheart v. State, 232 Ga. 247, 253, 206 S.E.2d 12, 17-18 (1974).

as Furman, 408 U.S. at 314 (White, concurring). See also Moore v. Zant, 722 F.2d 640, 646 (11th Cir. 1983) (Georgia trial courts must explicitly instruct sentencing jury that it has the option to recommend against death). Compare Brown, 107 S.Ct. at $839-40$ (upholding instruction that jury not reduce punishment out of mere sympathy).

st It may also actually further the goal of punishing criminals, for if mandatory sentences were allowed, a sentencing jury might refuse to convict a defendant facing a possible death sentence, if it felt capital punishment was not warranted in that case. See Woodson, 428 U.S. at 293 (plurality).

${ }^{85}$ See Washington v. Watkins, 655 F.2d 1346, 1376 n.57 (5th Cir. 1981) ("That asymmetry is offensive, however, only if one assumes that the grant of mercy to some, based on their particularized circumstances, somehow abridges the constitutional rights of others whose particular circumstances do not inspire mercy."). 
courts, upon finding an error in the proceedings below, to determine what the sentencer would have done if there had been no error. The appellate court must decide what the result of the trial would have been if the sentencer had heard a different bundle of evidence. This process is ill-suited to capital sentencing review.

First, where aggravating evidence has been erroneously admitted, the reviewing court must decide whether or not the sentencer would have sentenced the defendant to death without knowledge of this evidence. This assessment is, to be sure, somewhat similar to the determination of harmlessness in noncapital cases: both must look to specific, statutorily defined factors. ${ }^{86}$ But in a capital case, the sentencer has the freedom to decide how much importance to attach to aggravating circumstances; ${ }^{87}$ it may decide, on the basis of its observations at trial, that the aggravating circumstances are not very serious. Thus, the statutory definitions of aggravating circumstances act as only a partial constraint on the decision of the sentencer in a capital case: the sentencer may find some aggravating circumstances and yet still choose not to impose a death sentence. In noncapital cases or in the guilt phase of a capital case, on the other hand, the tribunal's choice is constrained as soon as it finds that the statutorily defined elements of a crime are present.

Furthermore, where mitigating evidence has been erroneously withheld, the reviewing court cannot determine what the outcome would have been if the sentencer had heard this evidence. The sentencer had discretion to impose mercy if it so chose. It is one thing to say that an appeals court working from a cold record finds it congenial to decide what a "reasonable" juror would have done in a particular circumstance; it is quite another to say that the same court can decide what a "merciful" juror would have done. The decision of the sentencer-be it jury or judge ${ }^{88}$-ratifies "community values"s8 that a distant reviewing court can neither duplicate nor, perhaps, understand. Since the sentencer must have discretion

s6 See Poland v. Arizona, 106 S.Ct. 1749, 1754 (1986).

${ }^{87}$ See Harvard v. Florida, 459 U.S. 1128, 1132-33 (1983) (Marshall, dissenting from denial of certiorari).

ss In Spaziano v. Florida, 468 U.S. 447, 461-62 (1984), the Court held that the death penalty need not be imposed by a jury; a jury's refusal to impose the penalty may be overridden by the trial judge where state law permits it.

aven in Spaziano, where the Court said that a judge as well as a jury may impose a sentence of death, the Court emphasized the importance of the "community's voice" in the sentencing process. Id. at 462 . See also Witherspoon v. Illinois, 391 U.S. 510, 528 (1968); Caldwell v. Mississippi, 472 U.S. 320, 330-31 (1985). 
to spare a defendant from execution, and that discretion contemplates acts of mercy, it is not only anomalous, but also impossible, for reviewing courts to undertake the rational inquiry outlined by Chapman. ${ }^{90}$

Finally, even if the reviewing court were able to predict the effect of the error with regard to a particular aggravating or mitigating factor, it still would not be able to carry out the harmless error test. The state (or the defendant, if the error is nonconstitutional) must show that the aggravating evidence outweighs the mitigating evidence. ${ }^{91}$ But it is the sentencer that decides how much weight to give to the aggravating and mitigating factors, and that decision is not amenable to appellate review. Because the sentencer may-indeed, must-consider all factors in whatever balance it chooses in deciding upon the sentence, the appellate court cannot determine either beyond a reasonable doubt or with a reasonable certainty what impact the aggravating or mitigating factor would have had on the decision.

Thus, the sentencer's discretion and its ability to impose mercy make it impossible for a reviewing court to weed out "harmless" error in capital sentencing proceedings. The reviewing court is simply unable to assess the impact of any error on the sentencer-both because of uncertainty over the error's place in the sentencer's deliberations and because of the sentencer's ability to impose life imprisonment instead of death whenever it chooses. When there is error, therefore, death sentences must be reversed. The premise of the harmless error doctrine is that the impact of errors on trial and sentencing courts can be assessed by appellate courts. Where this assessment is impossible, the doctrine should not apply.

This assessment is not based on a judgment that the death penalty is illegitimate. The defendant in a capital sentencing proceeding has no right to a particular outcome any more than a defendant in any other criminal proceeding. But he certainly has a "legitimate interest in the character of the procedure which leads

so See Caldwell, 472 U.S. at 330, quoting Woodson, 428 U.S. at 304 (plurality): "Whatever intangibles a jury might consider in its sentencing determination, few can be gleaned from an appellate record. This inability to confront and examine the individuality of the defendant would be particularly devastating to any attempt for consideration of what this Court has termed '[those] compassionate or mitigating factors stemming from the diverse frailties of humankind.' " Consider also McCleskey, 107 S.Ct. at 1767 ("Each jury is unique in its composition, and the Constitution requires that its decision rest on consideration of innumerable factors.").

1 See Pulley, 465 U.S. at 52. 
to the imposition of sentence.",92

Harmless error analysis in capital sentencing is inappropriate for nonconstitutional errors as well as constitutional ones. Ordinarily, the Court refuses to require automatic reversal for nonconstitutional errors, ${ }^{98}$ but its reluctance to do so must, again, depend on its confidence in the courts' ability to ferret out errors that influ- . enced the trial outcome.

Moreover, any error in capital sentencing implicates some constitutional concerns. The constitutionally compelled sentencing discretion in capital punishment proceedings may be undermined by error regardless of whether an independent constitutional right is violated. For example, consider a case in which a piece of mitigating evidence is excluded under an erroneous construction of a state's rules of evidence. Although this mistake does not itself violate the defendant's constitutional rights, it constricts the defendant's constitutionally required opportunity for mitigation and mercy. Since the sentencer may not impose the death penalty if it finds even one mitigating factor, it must follow that the erroneous exclusion of just one piece of mitigating evidence necessitates resentencing. As the Supreme Court has time and again stressed, the stakes are extraordinarily high in such cases-too high to risk error.

The above conclusions contain their own limiting principle, illustrated by the following syllogism. Error in capital sentencing proceedings is constitutionally troublesome only when an appellate court cannot assess the impact of the error on the sentencer. To assess the impact of an error on the sentencer, the appellate court must put itself in the shoes of the sentencer. The appellate court is unable to do so only when the character of the proceedings below would have been different if the error had not occurred-or, in other words, when the error affects the balance of factors that the sentencer must consider. Evidentiary errors change the character of proceedings by altering the menu of proof. Structural errors do not change the character of the proceedings themselves because, by definition, they are mistakes that occur on the perimeter of the conduct of the litigation.

Thus, while the appellate court is able to assess the impact of structural errors, it is unable to assess the impact of evidentiary errors on the sentencer. The harmless error doctrine therefore may be applied to the former but not to the latter in capital sentencing

22 See Gardner, 430 U.S. at 358 (Stevens, concurring).

's See Kotteakos, 328 U.S. at 764-65. 
proceedings. This limitation ensures that the costs associated with automatic reversal-such as the use of scarce judicial resources-will not be too great. In any event, constitutional interests may not be sacrificed in order to spare society such costs.

\section{CONCLUSION}

A per se rule requiring automatic reversal once evidentiary error in capital sentencing proceedings is found will bring additional safeguards to capital sentencing without seriously affecting the harmless error concerns of judicial economy and justice. Errors that affect the evidence presented to the sentencer present a powerful case for application of a rule of absolute reversal. Because of the inability of the reviewing court to determine the impact of such errors on the sentencer, the Chapman test should not be used to determine the harmlessness of error in capital sentencing.

James C. Scoville 